\title{
CLIMA URBANO SOB O OLHAR DAS PEQUENAS CIDADES: INFLUÊNCIA DOS FATORES GEOGRÁFICOS NAS VARIAÇÓES CLIMÁTICAS EM LAGOA FORMOSA (MG)
}

\author{
URBAN CLIMATE UNDER SMALL CITIES: INFLUENCE OF \\ GEOGRAPHICAL FACTORS IN CLIMATE VARIATION \\ IN LAGOA FORMOSA (MG) \\ CLIMAT URBAIN SOUS LES YEUX DES PETITES VILLES: \\ INFLUENCE DES FACTEURS GÉOGRAPHIQUES DANS LES \\ VARIATIONS CLIMATIQUES À LAGOA FORMOSA MG
}

Francielle de Siqueira Castro

Doutoranda em Geografia - Instituto de Geografia da Universidade Federal de

Uberlândia;

franciellesiqueiracastro2009@hotmail.com

Rildo Aparecido Costa

Professor do Curso de Geografia da Faculdade de Ciências Integradas do Pontal da Universidade Federal de Uberlândia;

rildocosta@ufu.br

Resumo: O ambiente urbano tem se tornado cada vez mais a morada do homem. Essa intrínseca relação homem/espaço urbano traduz-se na transformação da paisagem, resultando em diversos fenômenos ambientais urbanos como ilha de calor, efeito estufa, poluiçáo atmosférica, inversão térmica, impermeabilização do solo, dentre outras, que a longo prazo interferem na qualidade ambiental e na qualidade de vida dos citadinos. Desta forma, o objetivo desta pesquisa foi investigar as características do clima urbano (campo térmico e higrométrico), na cidade de Lagoa Formosa (MG), e como esses reagem sob a influência dos fatores geoecológicos e de estrutura citadina. O Sistema Clima Urbano de Monteiro (1976), foi a base para a proposição metodológica apresentada, utilizando o modelo de transectos móveis, que consiste na demarcaçáo e coleta de dados de temperatura, umidade do ar e direçáo e velocidade dos ventos em pontos espalhados pelo sítio urbano, de forma a abarcar, também, os espaços interurbanos. Além da aquisição de dados em pontos fixos. Os resultados permitiram detectar que a área urbana de Lagoa Formosa nem sempre apresenta temperaturas mais elevadas em relação ao seu entorno rural ou às áreas periféricas à cidade.

Palavras-chave: Clima urbano, temperatura, umidade relativa do ar, espaço urbano e Lagoa Formosa. 


\begin{abstract}
The urban environmenthas become more and more the home of man. This intrinsic relationship between man and urban space translates into the transformation of the landscape, resulting in several urban environmental phenomena such as heat island, greenhouse effect, atmospheric pollution, thermal inversion, soil waterproofing among others, which in the long term interfere with environmental quality and in the quality of life of city dwellers. In this way the objective of this research was to investigate the characteristics of the urban climate (thermal and hygrometric field) in the city of Lagoa Formosa (MG), and how they react on the influence of geoecological factors and city structure. The Monteiro Urban Climate System (1976) was the basis for the methodological proposal presented using the mobile transects model, which consists of demarcation and data collection of temperature, air humidity and direction and speed of the winds at points scattered throughout Urban site, to include interurban spaces as well. In addition to the acquisition of data in fixed points. The results allowed to detect that the urban area of Lagoa Formosa does not always present higher temperatures in relation to its rural surroundings or to the outskirts of the city.
\end{abstract}

Keywords: Urban climate, temperature, relative humidity, urban space and Lagoa Formosa.

Résumé: L'environnement urbain est devenu de plus en plus la demeure de l'homme. Cet espace urbain/homme relation intrinsèque se reflète dans la transformation du paysage, ce qui entraîne plusieurs phénomènes environnementaux comme îlot de chaleur urbain, le réchauffement climatique, la pollution atmosphérique, échange de chaleur, sol, étanchéité, entre autres, que dans l'effet à long terme sur qualité de l'environnement et la qualité de vie des gens des ville. L'objectif de cette recherche était d'étudier les caractéristiques du climat urbain (champ thermique ethygrométrique) dans la ville de Lagoa Formosa (MG), et comment ils réagissent sous l'influence de facteurs de geoecológicos et de la structure de la ville. Le système urbain de climat de Monteiro (1976), était la base pour la proposition méthodologique a présenté, en utilisant le modèle de transects meubles, qui consiste au marquage et collecte des données de température, humidité et vent de direction et la vitesse en points dispersés à travers le site urbain, donc embrasser, aussi, les espaces de transport interurbains. En outre également l'acquisition de données sur des points fixes. Les résultats ont permis de détecter que la zone urbaine de. Les résultats ont permis de détecter que la zone urbaine de Lagoa Formosa n'est pas toujours présente des températures plus élevées par rapport à ses environs rurales ou périphériques de la ville.

Mots-clés: Climat urbain, température, hygrométrie, espace urbain et Lagoa Formosa.

\title{
INTRODUÇÃO
}

O universo citadino está amplamente aberto ao que há de mais interdisciplinar, pois as cidades têm se tornado cada vez mais, a morada do homem, e constitui-se, portanto, em um lugar onde se produz economicamente, onde estão centralizados serviços, negócios, pessoas, automóveis, edificaçóes. A rápida multiplicação da população humana nos últimos anos e sua ocupação nos mais inimagináveis espaços nas áreas urbanas, acarretou na sua adaptação 
às condições a ele delimitadas, sejam estas: climáticas, topográficas, espaciais e/ou sociais. Atualmente essas alteraçóes têm ganhado visibilidade diante dos membros da comunidade científica, ambientalista, política, entre outras, na busca de discussóes para minimização de impactos gerados pela atuação do homem no ambiente, principalmente nas áreas urbanas.

Dentre as reconfiguraçóes propiciadas pela ação antrópica sobre o espaço urbanizado, as alteraçóes climáticas urbanas chamaram nossa atenção, para o desenvolvimento deste estudo. O reflexo da estreita relação entre os aspectos naturais e influência humana sobre o espaço urbanizado traduz-se em diversos fenômenos ambientais urbanos como ilha de calor, efeito estufa, poluição atmosférica, inversão térmica, impermeabilização do solo, dentre outras.

As preocupações com as alterações atmosféricas da cidade e de seus arredores têm sido tratadas antes mesmo da revoluçáo industrial e, com seu desenvolvimento, as inquietaçóes se tornaram mais evidentes, o que nos despertou para os primeiros estudos sobre o clima urbano. Porém, foram nas últimas três décadas (1980-2009) que o homem passou a observar, de forma mais atuante, as mudanças sensíveis nas escalas micro e mesoclimáticas.

No Brasil os estudos sobre o clima urbano ganharam destaque a partir da década de 1960 quando os problemas ambientais, como poluiçáo do ar e inundaçóes, se tornaram mais intensos, principalmente nas grandes metrópoles como Sáo Paulo e Rio de Janeiro. Esse fato colaborou para que estudiosos da área se preocupassem em expandir as pesquisas, no cenário brasileiro, sobre as alteraçóes climáticas.

Para Mendonça (2000), o interesse nos estudos de clima urbano nas últimas décadas tem se elevado nas cidades de porte pequeno e médio graças às maiores facilidades para o planejamento e as intervençóes urbanísticas, quando comparadas as lógicas metropolitanas, pois há "possibilidades de intervenção no ordenamento territorial da cidade, fato que é muito mais difícil em cidades de grande porte" (AMORIM, 2000, p. 22).

Lagoa Formosa é um município considerado, nos parâmetros do IBGE, de pequeno porte, e tem alcançado nos últimos anos um crescimento representativo com a ampliação de seus limites urbanos. Com essas transformaçôes, os estudos sobre o município ganham novas perspectivas em diferentes áreas do conhecimento. De acordo com os dados do Instituto Brasileiro de Geografia Estatística (IBGE, 2014), a população passou de 15.949 em 1991 para 17.161 em 2010 e, segundo o mesmo banco de dados a projeção para 2013 foi de 17.885 habitantes.

Assim, o objetivo desta pesquisa é analisar a influência dos fatores geoecológicos (altitude, elevação do relevo, disposição das vertentes e vegetação) e de estrutura citadina (espaços construídos, impermeabilização, espaços livres) nas variações climáticas na área urbana de Lagoa Formosa (MG), considerando sua estrutura térmica e umidade relativa do ar no inverno do ano de 2014. 


\section{CARACTERIZAÇÃO GEOGRÁFICA DO MUNICÍPIO DE LAGOA FORMOSA (MG)}

O recorte espacial do trabalho trata-se do município de Lagoa Formosa, localizado entre as coordenadas geográficas de $18^{\circ} 46^{\prime} 44^{\prime \prime} \mathrm{S}$ e 46 $24^{\prime} 28^{\prime \prime} \mathrm{O}$ (Mapa 1). Situa-sena Mesorregiáo Geográfica do Triângulo Mineiro e Alto Paranaíba e é uma das onze cidades que compóem a microrregiáo de Patos de Minas. Ocupa uma área de aproximadamente $844 \mathrm{~km}^{2}$ e faz limite com os municípios de Carmo do Paranaíba e Patos de Minas, ligados pela rodovia estadual BR-354.

Mapa 1 - Localização do município de Lagoa Formosa (MG), 2015

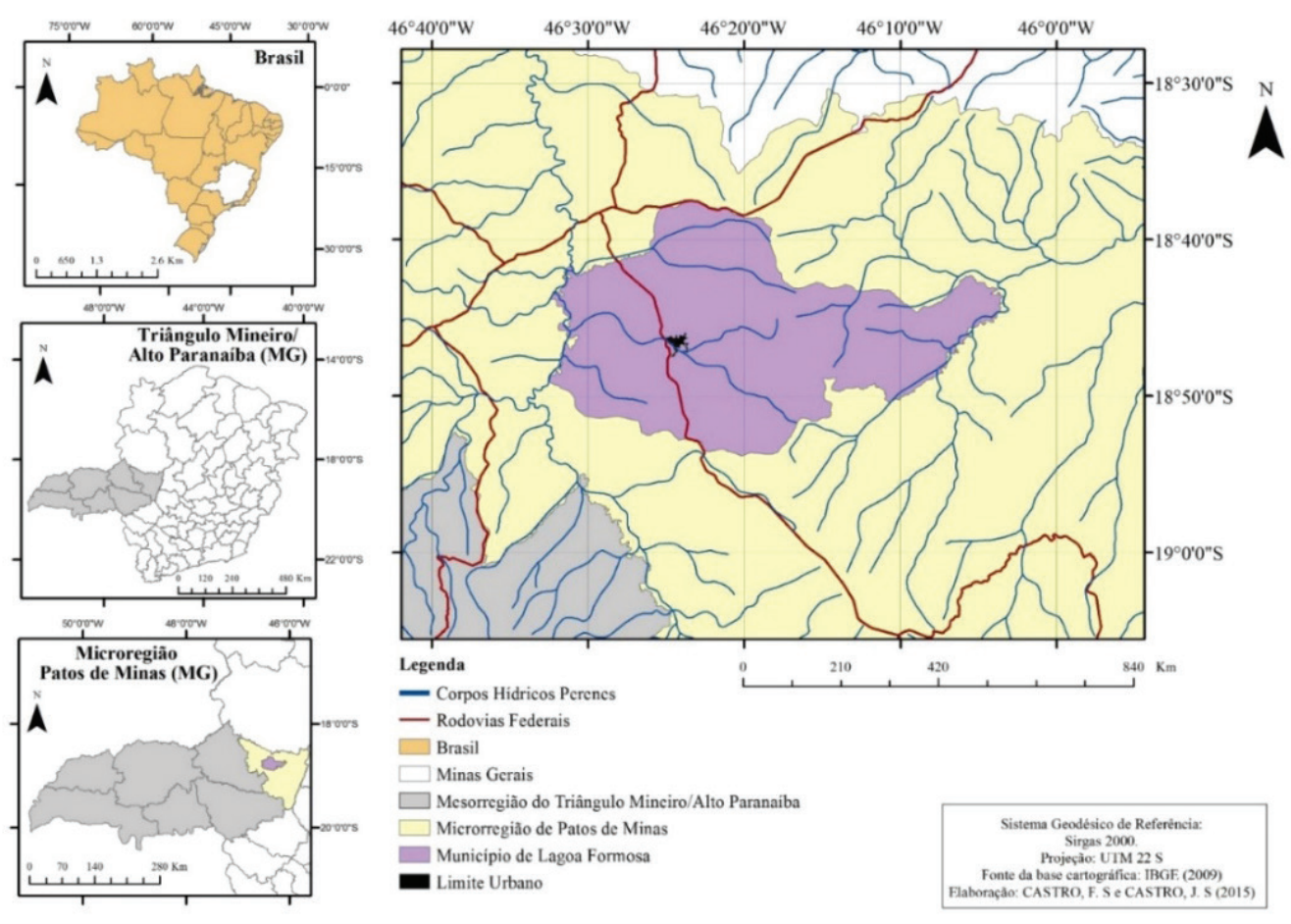

Fonte: IBGE, 2009

Os fenômenos climáticos atuantes apresentam intrínseca relação com os demais elementos físicos componentes da realidade local. Sendo assim, se torna indispensável que esses sejam correlacionados para a identificaçáo da realidade geoambiental, (relevo, geologia, geomorfologia, hidrografia e vegetação), da área urbana tomada para o estudo.

O município de Lagoa Formosa encontra-se em uma área de interflúvio, abarcando tributários dos Rios Paranaíba a oeste, que compóem a Bacia do Rio Paranaíba, e a leste o Rio Areado que, por sua vez, enquadra-se na Bacia do Rio Sáo Francisco.

O relevo é recoberto por áreas de domínio do cerrado, florestas estacionais semidecíduas (Mata Atlântica) e as áreas de campos rupestres (campos de altitude), domínio Morfoclimático que se concentra na regiấo do Planalto Central do Brasil, que reúne cerca de $23 \%$ do território brasileiro (NOVAIS, 2011). 
A configuração geomorfológica está atrelada à formação da geologia pretérita local, que apresenta feiçôes majoritariamente localizada na Bacia do São Francisco na porção centro-sul do cráton homônimo, especificamente pelas características diagnosticadas no Grupo Bambuí e no Grupo Mata da Corda.

O clima de forma geral é caracterizado como tropical, com verão quente e úmido; $\mathrm{O}$ inverno é seco, com temperaturas amenas. Um dos principais fatores dessas temperaturas pode ser associado à altitude de aproximadamente $902 \mathrm{~m}$. Essas características se encaixam na classificação climática de Köppen-Geiger como Aw, que, apesar de ser uma classificação genérica, ainda assim se aplica nos estudos para identificação inicial das características climáticas. Um clima tropical, com inverno seco, de maio a outubro, e estação chuvosa no verão, de novembro a abril. A temperatura média do mês mais frio é superior a $18^{\circ} \mathrm{C}$. As precipitaçóes são superiores a $750 \mathrm{~mm}$ anuais, podendo atingir níveis de até $1800 \mathrm{~mm}$.

\section{PRESSUPOSTOS TEÓRICOS E METODOLÓGICOS}

A complexa relação estabelecida entre a sociedade e a natureza tem estimulado o debate de estudiosos em diferentes facetas da comunidade científica. Instigados em conhecer as múltiplas relações estabelecidas pelos sistemas naturais e sociais, esses, criam e recriam abordagens científicas sobre elementos diversos.

O comportamento atmosférico, e sua atuação sobre as atividades humanas, incitou os grupos sociais a procurarem resposta para as diferentes intempéries provocadas pelos fenômenos climáticos. Para tanto, o desenvolvimento da ciência climatológica, como aquela que se destina a entender tais fenômenos, ganha força no cenário científico.

A construção epistemológica da climatologia tem suas bases apoiadas na Meteorologia, que por sua vez se dedica ao estudo da atmosfera e dos fenômenos que a cercam, preocupando-se com o registro e a medição destes fenômenos. A ciência meteorológica como muitas das outras ciências, se compartimenta em duas linhas de desenvolvimento: a Meteorologia Tradicional e a Meteorologia Dinâmica (CASTRO E COSTA, 2016).

Hann (1884, apud MONTEIRO, 1976, p. 6) discute o clima como um "conjunto dos fenômenos meteorológicos que caracterizam a condição média da atmosfera sobre cada lugar da Terra”. Apesar de ser o conceito fundamental para definição de clima, o mesmo demonstra carências na definição. em primeira instância, a atribuição de média destitui a realidade para caracterizar os elementos do clima e, em segundo lugar, o caráter estático, artificial, náo menciona o desenvolvimento dos fenômenos no tempo.

A aplicação das definições estabelecidas por Hann certamente não se relaciona aos estudos climáticos regionais ou mesmo locais, visto que, nesse caso, a média pode não responder aos questionamentos levantados, pois os eventos ocasionais marcantes dentro de um período, muitas vezes, não são revelados nas médias. Sendo assim, o clima deve ser visto como um fator em constante movimento. 
$\mathrm{Na}$ tentativa de transpor a limitação ocasionada pela proposição do autor supracitado, Sorre (1934) indica um caráter dinâmico ao clima, sendo o mesmo "uma série de estados atmosféricos acima de um lugar em sua sucessão habitual”. Sorre (op. cit. apud TARIFA, 2001, p. 12). Propóe-se, desta maneira, um novo modelo aos estudos climáticos, substituindo-se a média pelo ritmo. Isso faz com que a sucessão dos estados atmosféricos (tipos de tempo) seja observada por meio da interação dos elementos climáticos associados à circulação atmosférica.

O ambiente urbano, socialmente produzido, carrega consigo profundas mudanças no balanço de energia produzido e os resultados mais observados são traduzidos em ilhas de calor/frescor, conforto/desconforto térmico, poluição e precipitação excessiva (inundaçóes). Essas variações produzem uma alteração no ritmo climático, com secas intensas, chuvas calamitosas em determinadas regióes, gerando, dessa maneira, perceptíveis mudanças nas sucessóes dos estados atmosféricos se comparado ao clima de períodos anteriores.

Mendonça (2009, p. 182) destaca que os estudos que compreendem as cidades de médio e pequeno porte, objetos de estudo dos pesquisadores do clima urbano no Brasil, têm como enfoque central o campo termodinâmico, devido à sua condição de tropicalidade, que em muitos casos, eleva o desconforto térmico. Além de apresentar características geográficas diferenciadas daquelas de grande porte e metropolitanas, outra característica marcante das cidades desse porte é a facilidade para identificação de suas paisagens intraurbanas, o que permite uma melhor compreensão da interação sociedade-natureza na construção do clima urbano.

Os trabalhos a despeito do clima urbano das cidades de pequeno e médio porte têm registrado a existência de um clima específico para estas localidades. Diferentes autores, dentro os quais destacam-se, Cruz (1995), Amorim (2000) e Mendonça (2009) apontaram em seus estudos, os efeitos do progresso intenso de urbanização em cidades de pequeno porte.

De acordo com Cruz (1995, p. 7), “as cidades médias ou pequenas, pouco ou náo industrializadas e com pequena densidade populacional poderiam manifestar o fenômeno ilha de calor como os grandes centros, isto porque, os fatores inerentes à urbanização estavam presentes”. Porém, diferentemente das grandes, elas podem receber açôes de forma mais eficaz e crescerem apoiadas em um planejamento ambiental urbano mais adequado. Para tan to o sucesso da identificação do clima urbano se apoia na adequação metodológica para a realidade do experimento.

\section{DESCRIÇÃO DOS MATERIAIS E MÉTODOS UTILIZADOS NA PESQUISA}

A pesquisa documental proporcionou a aquisição de informaçóes para caracterizar, a priori, o município de Lagoa Formosa (MG) através do levantamento de dados estatísticos e censitários no Instituto Brasileiro de Geografia e Estatística (IBGE), na Prefeitura Municipal de Lagoa Formosa (MG), na Câmara Municipal de Lagoa Formosa (MG) e em demais órgãos que disponibilizem materiais referentes às realidades socioeconômicas do 
município. O Instituto Nacional de Pesquisas Espaciais (INPE) e o Instituto Nacional de Meteorologia (INMET) foram consultados auxiliando na aquisição de dados complementares na realização da pesquisa.

A partir da teoria proposta por Monteiro (1975), foi adotado o método dos transectos móveis (coleta nos horários das 9 h, 15 h e $21 \mathrm{~h}$ ), que consiste na demarcaçáo de pontos espalhados pelo sítio urbano de forma a abarcar, também, os espaços intraurbanos considerando os diferentes aspectos geográficos encontrados nos pontos. Para tanto, foram adquiridos dados térmicos, higrométricos e de direção e velocidade dos ventos.

Para a cidade de Lagoa Formosa (MG) foram escolhidos nove pontos no sentido norte-sul. Por não contar com estação meteorológica com dados diários não foi possível executar a análise rítmica e nem mesmo a comparação dos dados coletados pelo transecto. A fim de complementação dos dados, foram instalados três pontos fixos triangulados na malha urbana. Os pontos selecionados para aquisição dos transectos móveis contam com características de arborização, edificações, fluxo de veículos e pessoas e altimetria diferenciados, além da localização em áreas de uso e ocupação do solo distintos, demonstrando a variabilidade do microclima em áreas, pouco ou muito urbanizadas; periurbanas; com influência de espaços verdes, entre outros.

Já os pontos fixos foram instalados em residências localizadas fora do eixo de coleta dos transectos móveis, propiciando nas análises a triangulação dos dados para fins comparativos e de mapeamento.

Os dados foram coletados no período do inverno no ano de 2014, tentando visualizar a sazonalidade do inverno para a cidade. Para o inverno as mediçóes aconteceram no período que compreendeu os dias 27 de julho a 05 de agosto de 2014, escala temporal de dez dias.

Figura 1 - Lagoa Formosa (MG): localização dos pontos de experimento, 2014

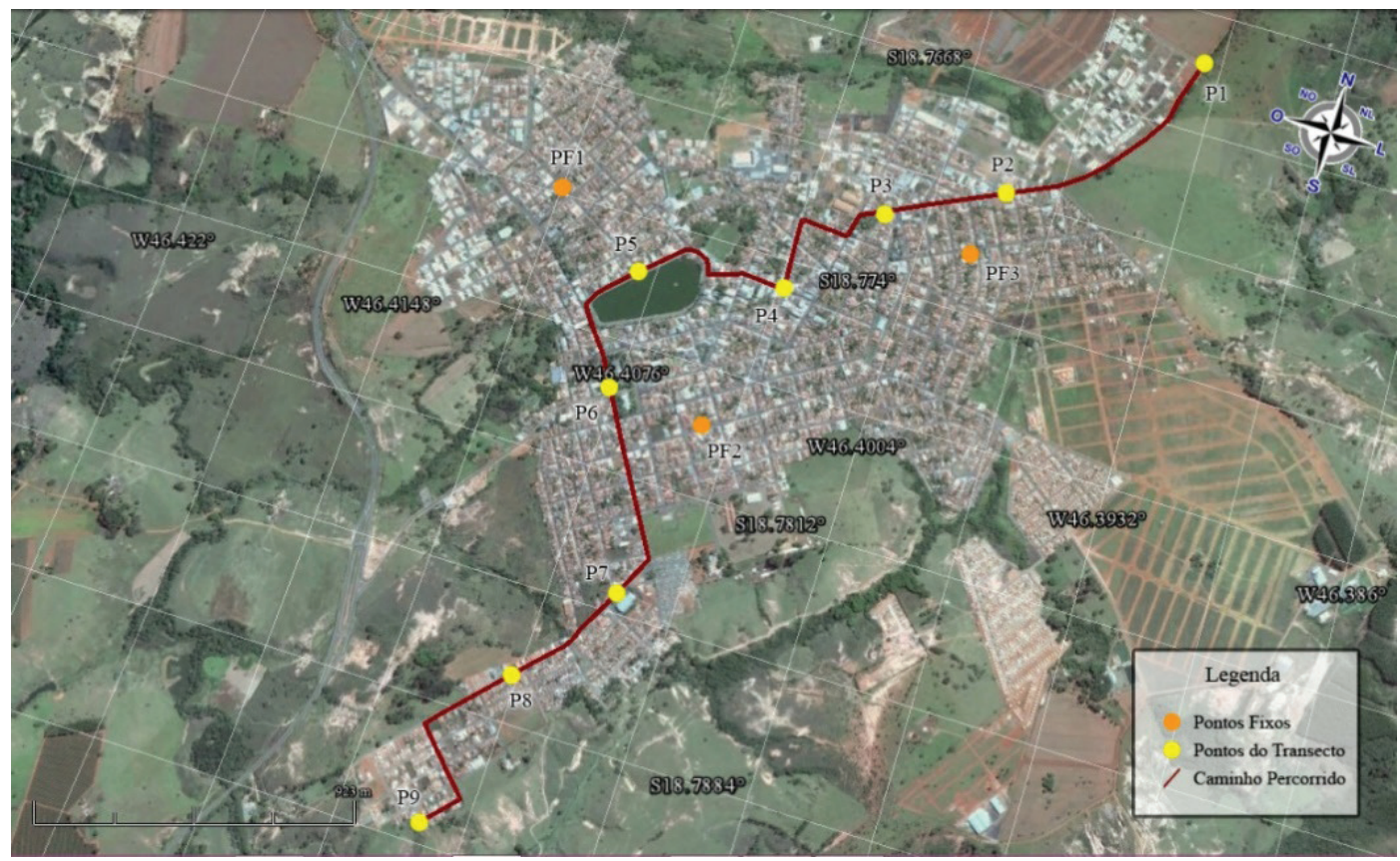

Fonte: Google Earth, 2014. 
A designaçáo dos horários para a coleta de dados do transecto móvel e dos pontos fixos, da referida pesquisa, obedeceu ao horário padrão do INMET - Instituto Nacional de Meteorologia que segue a designaçáo dada pela Coordenada de Tempo Universal (UTC), sendo os horários padróes $00 \mathrm{~h}, 06 \mathrm{~h}, 12 \mathrm{~h}, 18 \mathrm{~h}$ UTC, transformado para o horário brasileiro teremos 03 h, 09 h, 15 h e 21 h. Porém, como método de adaptabilidade, excluiu-se para a pesquisa as mediçóes no horário das três horas.bOs dados foram adquiridos por aparelhos climatológicos. (Figura 5)

Após a aquisição dos dados em campo, os mesmos foram sistematizados e organizados intuindo uma melhor interpretação e, consequentemente, um resultado mais confiável possível. Os dados climáticos coletados em campo foram organizados, inicialmente, em planilhas do Microsoft Excel versão 2010, e, posteriormente, representados através de climogramas, tabelas e gráficos também elaborados no Microsoft Excel.

Figura 2 - Aparelhos utilizados no experimento

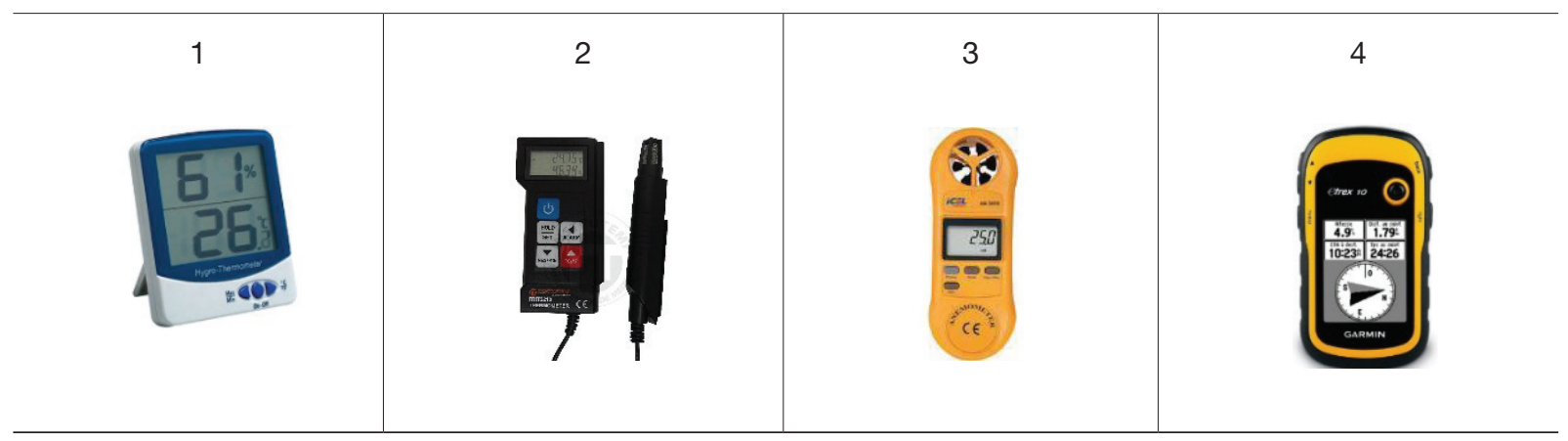

Fonte: Google imagens, 2014. 1) data logger; 2) termo-higrômetro digital portátil;

3) termo-anemômetro digital e 4) GPS

Como método comparativo, os dados foram especializados através da interpolação e representação espacial com o auxílio de softwares, cuja função é a elaboração de cartogramas de isovalores atribuídos ao campo termo-higrométrico. Organizadas em escalas de cores para os valores adquiridos demonstrando a distribuição espacial da temperatura e da umidade no espaço urbano em todos os episódios, para os três horários de coleta, produzidas pelo programa de mapeamento ArqGIS a partir da interpolação dos dados obtidos em superfície pelo método de $I D W$.

No intuito de avaliar a variação da temperatura e umidade relativa em sua dimensão espacial e temporal, optou-se pela utilização do Software Surfer 11 a partir da interpolação dos dados obtidos em superfície pelo método de Krigagem. A partir dessa representaçáo foi possível verificar a variação espaço-temporal dos índices extremos de temperatura em relaçáo aos valores medidos em ambiente periurbano, os principais horários e os setores de ocorrência das maiores e menores temperaturas, a magnitude das diferenças térmicas tendo sempre como parâmetro os dados do espaço periurbano.

Junto às análises realizadas em campo foram obtidas, junto ao Instituto Nacional de Pesquisas Espaciais (INPE), as Cartas Sinóticas de cada episódio para avaliação e 
correlação das informações da circulação atmosférica nos horários adotados. Além dos valores de temperatura e umidade relativa do ar, foram avaliados, também, a direção do vento e sua intensidade, tendo como parâmetro a Escala da Força de Vento de Beaufort (FORSDYKE, 1975).

\section{A INFLUÊNCIA DA ESTRUTURA CITADINA SOBRE O CLIMA URBANO}

No período das primeiras observações (nove horas), as temperaturas oscilaram no transecto móvel de $17,2{ }^{\circ} \mathrm{C}$ a $19,3{ }^{\circ} \mathrm{C}$. O ponto com maior temperatura registrada $\left(19,3^{\circ} \mathrm{C}\right.$ ) foi o ponto 9 (Rua Jovino Ferreira Coelho/João do Jó - Bairro Babilônia), o mesmo se encontra em área próximo ao meio rural, porém a atuação dos ventos no local é fraca devido à localização em uma área com menor altitude $(841 \mathrm{~m})$, se comparada aos demais pontos de experimento. Apesar de o percentual de umidade ter registrado $81,9 \%$, o mesmo esteve entre os mais baixos, juntamente com o ponto 3 que registrou $80,9 \%$.

Já o ponto 5, caracterizado pela presença da Lagoa D’água, que aparece como regulador térmico e consequentemente por estar em uma área aberta, possibilita a circulaçáo dos ventos atuantes e provavelmente contribuiu para amenizar a temperatura e estabelecer uma alta na umidade relativa do ar $\left(17,4^{\circ} \mathrm{C}\right.$ e $\left.86,3 \%\right)$.

Já no período da tarde, 15:00, as maiores temperaturas registradas no transecto foram nos pontos $2\left(20^{\circ} \mathrm{C}\right)$, que apesar de encontrar-se em área próxima ao rural, apresenta em seu entorno indústrias e galpóes. Já o registro de menor umidade do ar $(84,5$ $\%)$ ocorreu no ponto 6 localizado no centro da cidade constituída por uma diversificada vegetação, porém, a diferença do mesmo para os demais registros de umidade foi de aproximadamente $4 \%$ apenas.

O valor de umidade mais alto foi registrado no ponto $7(88,8 \%)$, que também se destacou por apresentar a menor temperatura do horário $\left(17,4^{\circ} \mathrm{C}\right)$. No período anterior, o ponto supracitado, permeou entre os maiores índices e uma das possíveis explicaçóes para tal divergência encontra-se na atuação dos ventos presentes no ponto no horário da coleta, que alcançaram a marca de $0,5 \mathrm{~m} / \mathrm{s}$.

Observou-se que às $21 \mathrm{~h}$, os valores de temperatura e de umidade apresentam uma característica de regularidade nos valores. O maior registro para os pontos de transecto foi no ponto $1-16,8{ }^{\circ} \mathrm{C}$ e $15,2{ }^{\circ} \mathrm{C}$ que foi o menor valor registrado no ponto 5 , ou seja, uma diferença de $1,6^{\circ} \mathrm{C}$. O ponto fixo 3 apresentou o maior registro entre os demais pontos fixos e do transecto, $\operatorname{com} 17^{\circ} \mathrm{C}$, e o menor índice de umidade $(88,7 \%)$.

A espacialização dos dados na prancha 1 demonstra o padrão de aquecimento pela manhã nas regióes nordeste e extremo sul da área urbana, onde encontram-se os pontos com índices térmicos mais elevados, ponto 1, ponto 2 a nordeste e no extremo sul representados por ponto 7 , ponto 8 e ponto 9 . Nesses pontos também são encontrados bolsôes de baixa umidade. 


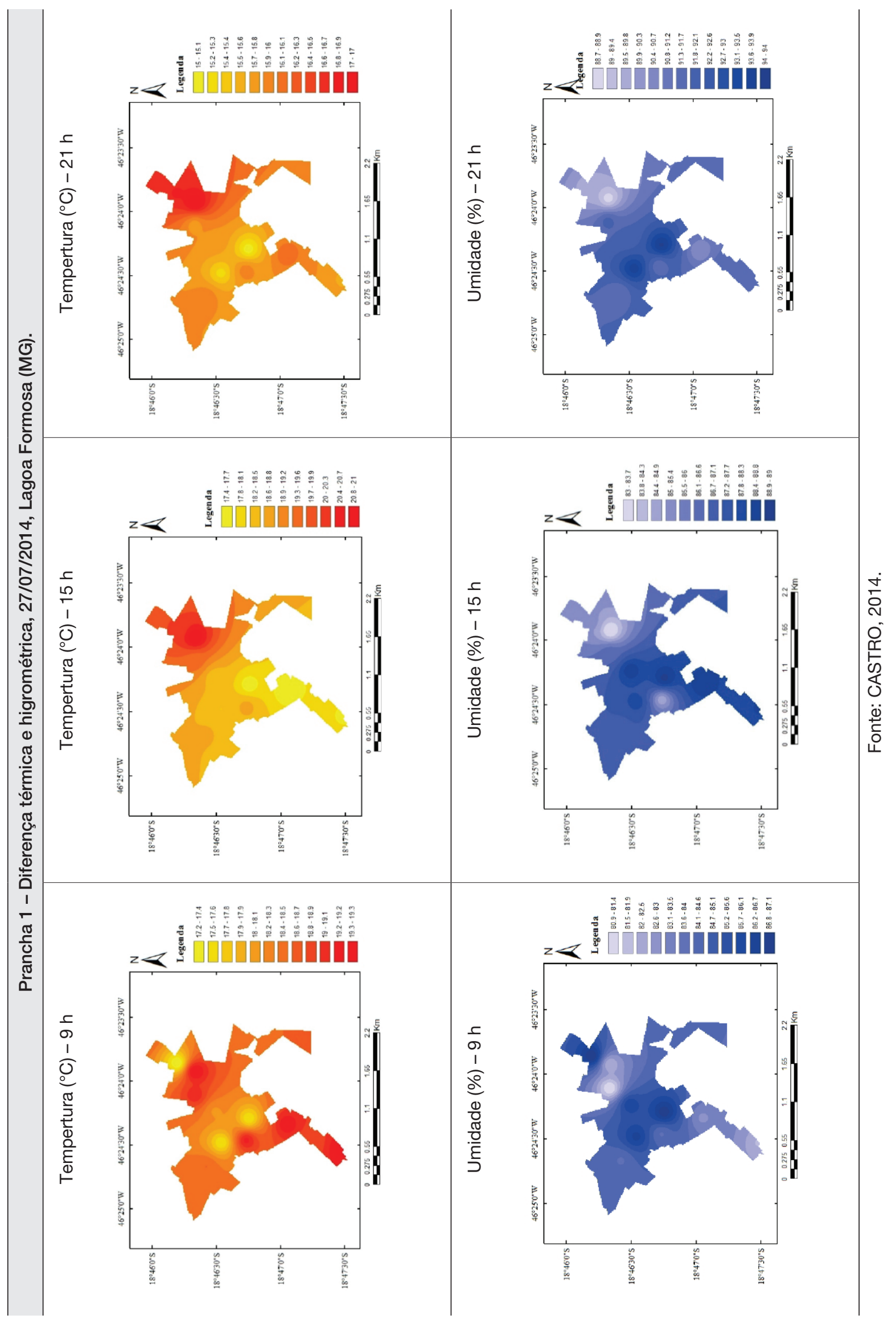


No período da manhá, do dia $28 / 07 / 2014$, tivemos nos pontos 1 e 2 do transecto as menores temperaturas, $17,4^{\circ} \mathrm{C}$ e $17,7^{\circ} \mathrm{C}$, e os maiores índices de umidade, ambos com $81,8 \%$. A temperatura amena no primeiro ponto provavelmente é explicada pela localização em área rural e ambos os pontos estáo sob a influência dos ventos, cuja velocidade registrada foi de $3,0 \mathrm{~m} / \mathrm{s}$ para o ponto 1 e $1,5 \mathrm{~m} / \mathrm{s}$ para o segundo.

Na prancha 2 é possível notar que as regióes com maior aquecimento no período da tarde se inverteram e a região que pela manhã se mostrou mais amena, nesse período do dia foi a de maior aquecimento, regiáo nordeste. Além disso, o ponto (regiáo sudeste) também se apresentou mais aquecido. Percebemos uma tendência de aquecimento na regiấo central da cidade.

À tarde, às quinze horas, as temperaturas mais elevadas foram registradas nos seguimentos 1 , 4 e 8 , com valores na casa dos $24^{\circ} \mathrm{C}$; o ponto 4 foi o que apresentou o menor índice de umidade (58,2\%). O mesmo se encontra na área central da cidade, composta por estabelecimentos comerciais e residenciais, com movimentaçáa intensa de pessoas e veículos, além de ausência de vegetação no local.

As regióes mais úmidas do período são aquelas apresentadas pelos pontos fixos 1 e 2 , diagnosticadas na prancha pela porção sudoeste e noroeste da malha urbana, onde também os padróes térmicos são mais amenos.

No período noturno há uma queda nas temperaturas, característica do período de inverno. Os pontos fixos 2 e 3 apresentaram valores térmicos na casa dos $20^{\circ} \mathrm{C}$, enquanto os demais pontos pesquisados não ultrapassaram os $18^{\circ} \mathrm{C}$. Os pontos próximos ao rural (P1 e P9) foram aqueles que se apresentaram mais frios, com registros aproximados a $16,5^{\circ} \mathrm{C}$. O índice de umidade para o período supracitado manteve-se na casa dos $80 \%$ até $87 \%$. Além do ponto fixo 1, que apresentou o valor mais elevado (87\%), tivemos também o registro de $86,6 \%$. 


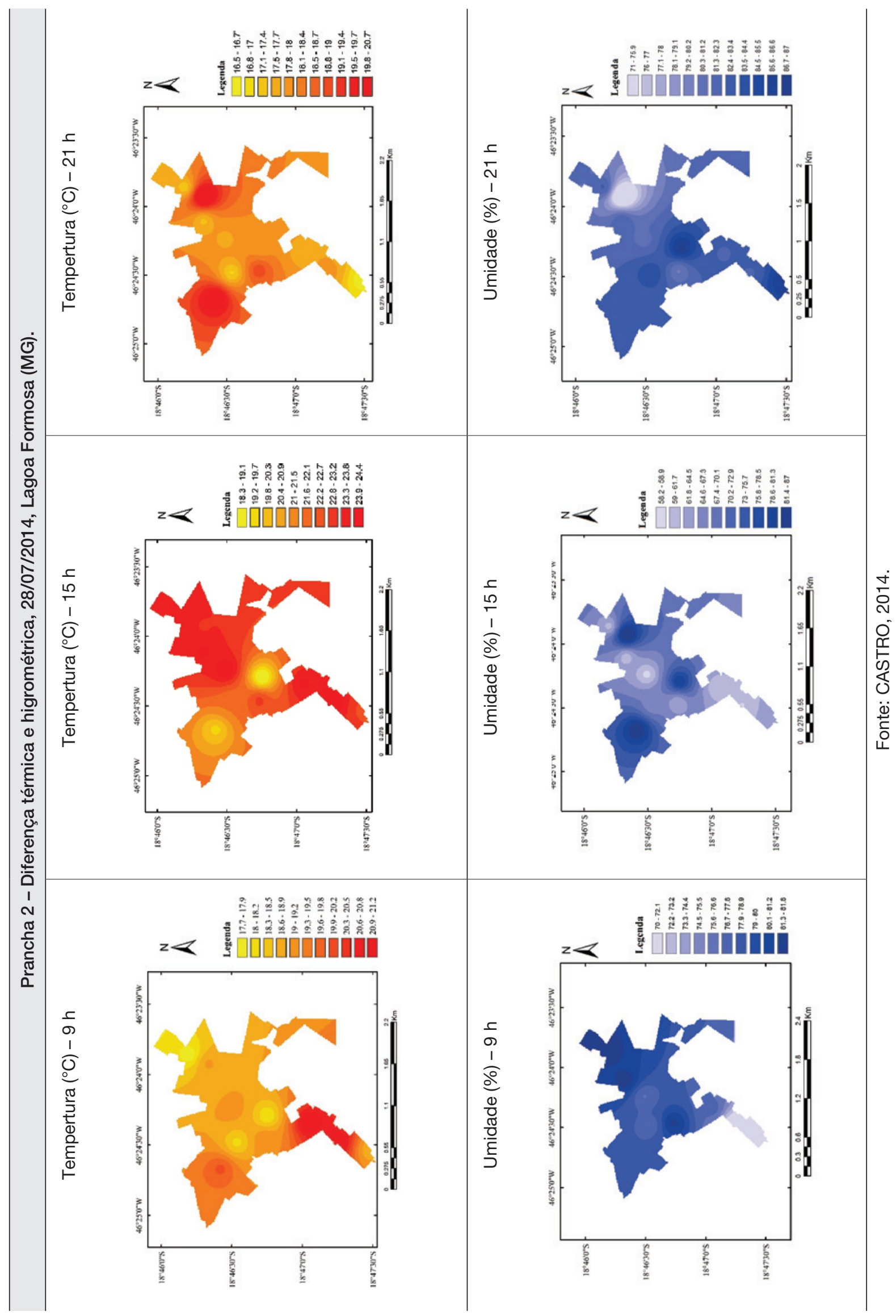


Às nove horas as temperaturas tiveram variação de $17^{\circ} \mathrm{C}$ a $20^{\circ} \mathrm{C}$. O maior valor registrado ficou por conta dos pontos 6,7 e 8 ; os mesmos se encontram no final do percurso, onde as altitudes tendem a baixar e os ventos não conseguem alcançar com tanta intensidade o que provavelmente pode inferir nas temperaturas registradas.

Foram registrados ventos contínuos e intensos em alguns locais, em destaque estáo $\mathrm{P} 1$, com ventos para sudoeste de intensidade $4,0 \mathrm{~m} / \mathrm{s}$, ponto $5 \mathrm{com}$ velocidade de 2,9 $\mathrm{m} / \mathrm{s}$ e o ponto 9 marcando $5,6 \mathrm{~m} / \mathrm{s}$.

No período vespertino $(15 \mathrm{~h})$ as temperaturas sobem e o maior registro $27,7^{\circ} \mathrm{C}$ encontra-se na Rua Jucá Limírio/Rua Francisca F. Canedo, centro comercial da área urbana, onde concentra-se o maior fluxo de pessoas e veículos abarcando também as edificações mais altas (estas edificaçóes atuam muitas vezes como barreira na circulação dos ventos). Quanto ao índice de umidade, o valor de menor expressão, ou seja, a região mais seca foi registrada no ponto 9 seguido pelo ponto 6 .

Já o ponto que obteve menor índice térmico e maior umidade foi novamente o ponto 5 (Orla da Lagoa), marcando $22,1^{\circ} \mathrm{C}$ e $65,1 \%$. Os ventos registrados estavam nos sentidos noroeste e sudoeste, no ponto $3(0,4 \mathrm{~m} / \mathrm{s})$ e no ponto $7(3,9)$.

Os mapas apresentados na prancha 3 apresentam um padrão nos pontos aquecidos de manhã e à tarde, sobre as regióes centrais, a sudoeste e ao sul, representando também as regióes mais secas, porém no extremo sul as nove horas, as temperaturas se apresentaram mais amenas. Nos dois horários temos na regiáo sobre influência do ponto fixo $1 \mathrm{e}$ 2 e também dos pontos de transecto 3 e 5, as temperaturas mais amenas, como apontam os dados descritos acima. Nesses mesmos pontos a umidade permanece alta. 


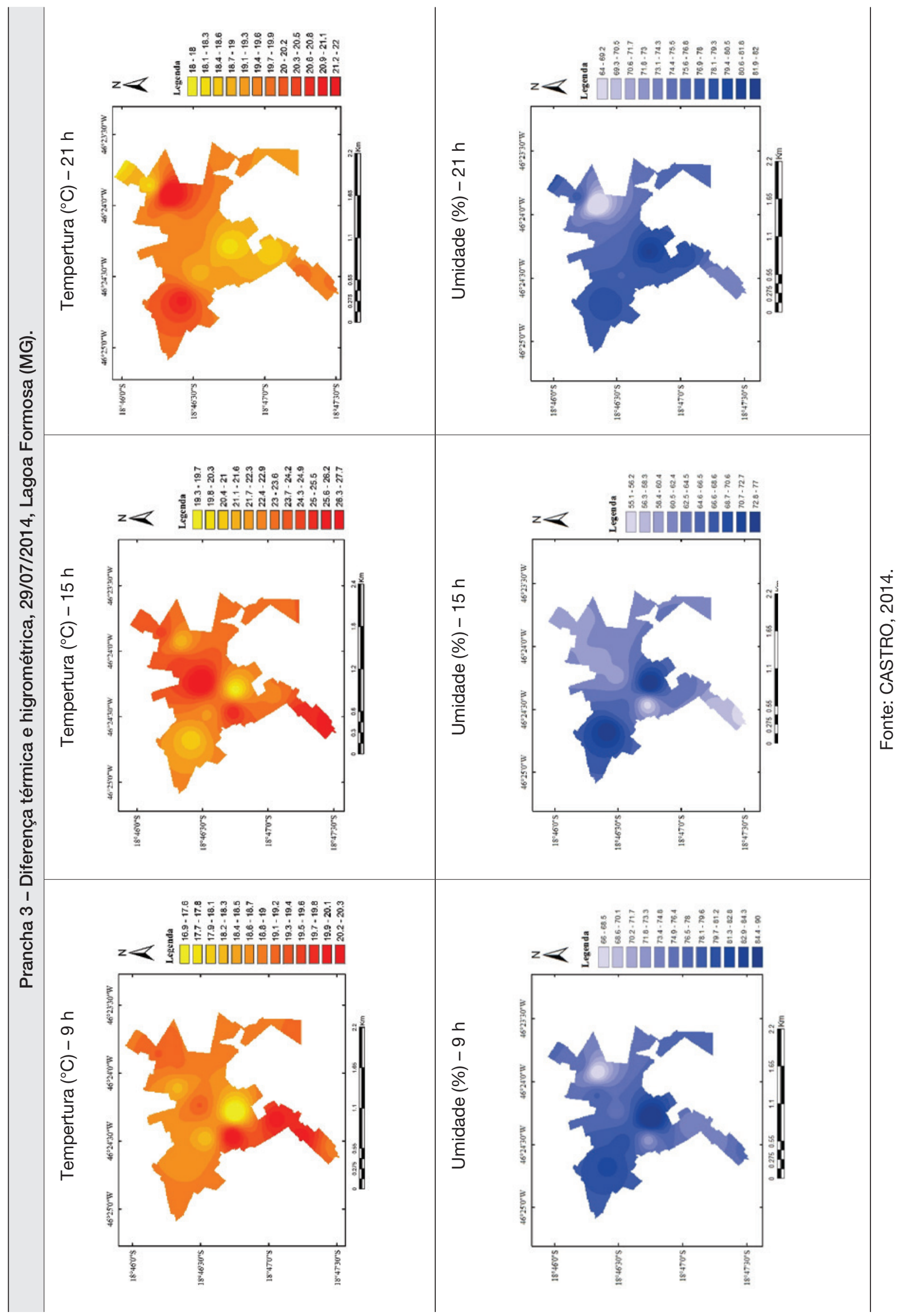


Já nas espacializaçôes de temperatura e umidade noturna, o extremo nordeste e as porçóes sudoeste apresentam características de resfriamento, vistas também a sudeste. Diatrinta as características atmosféricas permaneceram as mesmas com presença de nuvens esparsas e com atuação de ventos constantes durante os três horários do dia.

O ponto fixo 1 , às $9 \mathrm{~h} 99 \mathrm{~min}$, foi aquele que registrou a menor temperatura $16,7^{\circ} \mathrm{C}$, junto a ele o ponto $5\left(19,2^{\circ} \mathrm{C}\right)$ o ponto $3\left(19,5^{\circ} \mathrm{C}\right)$, um seguimento constituído pela Praça Ladislau Ferreira Coelho, que apesar de não ser de grande porte é bem arborizada com alta permeabilidade, ambos registraram valores mais amenos nas temperaturas.

Como citado no início desta descrição, os registros de umidade tiveram uma queda, se comparados aos dias anteriores. Tirando os pontos fixos $1(82 \%)$ e $2(75 \%)$, todos os outros pontos registraram valores entre 62 e 69 \% de umidade. Em consonância aos registros de temperatura, os percentuais de maior umidade, $69,2 \%$ e $68,5 \%$, foram registrados nos pontos de segmento móvel, ponto 5 e ponto 3 , respectivamente.

Nos pontos 4 e 6 que houve maior elevação na temperatura do período $\left(25^{\circ} \mathrm{C}\right)$, que também aparece no ponto fixo 3 . A elevação da temperatura no ponto 4 é observada com recorrência nos experimentos e as explicaçôes mais prováveis nesta situação apoiam-se na localização, em regiáo central da cidade, e ainda na atuaçáo restrita dos ventos, observados em outros pontos.

O período noturno apresentou as temperaturas mais amenas do dia com média de $19^{\circ} \mathrm{C}$. Já os percentuais de umidade permearam a casa dos $70 \%$. O ponto 9 apresentou, dentre os valores térmicos, o menor registro, $16,3{ }^{\circ} \mathrm{C}$, e contou com a maior umidade do ar que foi de $79,7 \%$. Isso pode ser explicado pela localização do ponto em área próximo ao rural e com ocorrência de corpos hídricos circundantes à área.

A prancha 4 apresenta a dinâmica das temperaturas e umidade ao longo do percurso. há de se perceber que é no período da tarde que acontece a maior distinção entre as regióes mais aquecidas e aquelas que se apresentam mais amenas, sendo que as regióes central e nordeste foram aquelas com maior destaque no padráo de aquecimento e na baixa umidade. 


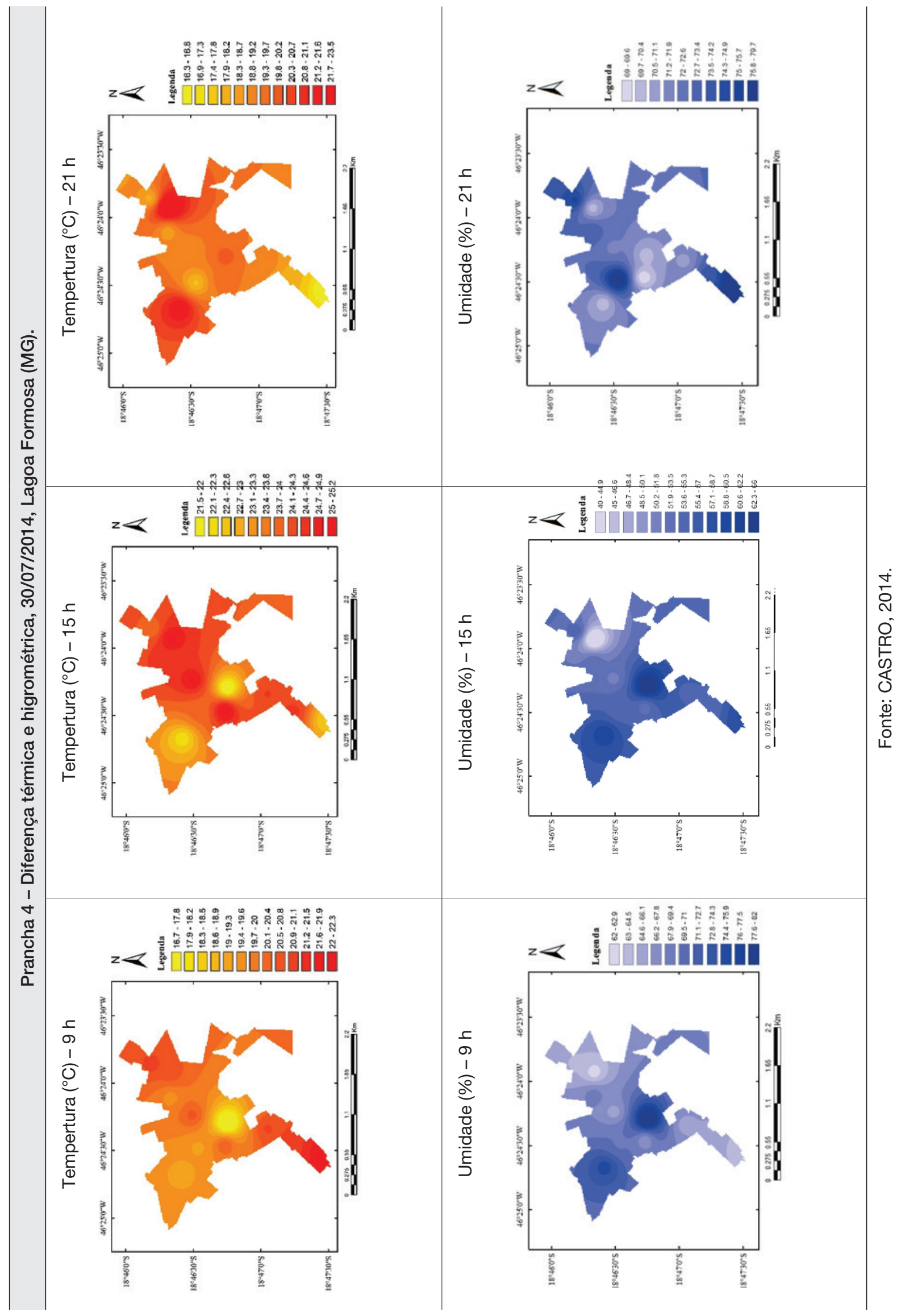


O dia 31 de julho de 2014 amanheceu com céu claro, sem a presença efetiva de nuvens. Isso significa que tenho radiação direta e, por isso, a temperatura aumenta, além de aumentar a sensação térmica. Os ventos não foram constantes, sendo mensurados apenas no período da tarde.

Às nove horas as temperaturas foram registradas entre $20,7^{\circ} \mathrm{C}$ e $23,7^{\circ} \mathrm{C}$, o ponto menos aquecido correspondeu ao ponto 1 , e o mais aquecido ao ponto 8 . Isso significa que as diferenças entre as temperaturas alcançaram até $3{ }^{\circ} \mathrm{C}$. Essa diferença também esteve presente nos pontos fixos, porém com $0,6^{\circ} \mathrm{C}$ a mais que dos transectos.

Os registros de umidade tiveram em média o percentual de $55 \%$. Fugindo desse padrão o ponto 1 apresentou o maior índice, $62 \%$, e o menor valor de umidade, 40,7 $\%$, esteve presente no ponto 7 . Nos pontos fixos a umidade média foi maior $69 \%$, pois o ponto fixo 1 e 2 registraram percentuais elevado de $79 \%$ e $75 \%$.

Às quinze horas as temperaturas se mostram mais elevadas, com médias de $25,3^{\circ} \mathrm{C}$; as umidades acompanham esse aquecimento e tenderam a ter valores mais baixos. Nos transectos o ponto 4 apresentou índice de umidade de $38,3 \%$, sendo o mais baixo dentre os demais. As descrições anteriores apontam para uma recorrência nas baixas umidades para esse ponto, junto a ele o ponto 6 também apresentou baixa umidade, $39,1 \%$, pois ambos sofreram fraca atuaçáo dos ventos, a velocidade foi de $0,7 \mathrm{~m} / \mathrm{s}$ e 0,8 $\mathrm{m} / \mathrm{s}$ respectivamente.

Às vinte e uma horas, tem-se novamente uma queda nas temperaturas, aumento nos percentuais de umidade e os ventos não atuam em nenhum dos pontos de coleta. A média das temperaturas foi de $19{ }^{\circ} \mathrm{C}$ e a umidade permeou na casa dos $62,8 \%$.

O dia 01/08/2014permaneceu com céu claro, sem expressiva atuação de ventos durante as coletas de dados. A partir desse dia as temperaturas tiveram aumento representativo com queda de umidade, registrando momentos muito secos.

As temperaturas dos pontos de transectos (prancha 5), no período da manhã registraram temperaturas entre $20,5^{\circ} \mathrm{C}$ e $25^{\circ} \mathrm{C}$. Os pontos 1 e 3 foram os que registraram os menores índices térmicos $\left(20,5^{\circ} \mathrm{C}\right.$ e $\left.20,9^{\circ} \mathrm{C}\right)$, o primeiro se caracteriza pela proximidade com a área rural e a presença de eucaliptos plantados ao longo da estrada, o que possivelmente influi para que as temperaturas permaneçam mais amenas enquanto o ponto 3, que também apresenta maior índice de umidade $(64,1 \%)$, está localizado em uma área com arborização representativa, e somado a isso foi um dos pontos que contou com a presença de ventos.

Já os pontos de maior aquecimento foram os pontos 8 e 9 , ambos com $25{ }^{\circ} \mathrm{C}$. No final dos transectos observamos que, uma justificativa para esse aumento na temperatura, que pode estar na queda de altitude $(860 \mathrm{~m}-841 \mathrm{~m})$ em relação aos demais pontos, o que dificulta a circulaçáo dos ventos no local. Os pontos supracitados, juntamente com o ponto 7 , registraram os menores índices de umidade relativa do ar com valores de $51 \%$.

A prancha 6 demonstra que a porção sul foi plotada no mapa como a mais aquecida, acompanhada da região central, que também apresentou ligeiro aquecimento e baixa 
umidade. Já no extremo nordeste, juntamente as regióes noroeste e centro-sul, as temperaturas estiveram mais amenas enquanto a umidade mais elevada.

À tarde, a umidade nos pontos de transecto tiveram em média o registro de $35 \%$. $\mathrm{O}$ índice mais baixo foi de $34,1 \%$ no ponto 4 , que aparece com os indicadores de baixa umidade se comparado aos demais e nele também se encontra o maior indicador térmico, $30,5^{\circ} \mathrm{C}$. No ponto 1 constatou-se o registro mais elevado no índice higrométrico, $39,1 \%$, entre os pontos móveis e, junto a isso, a menor temperatura também esteve presente $\left(26,5^{\circ} \mathrm{C}\right)$, repetindo as características descritas no período da manhá.

Os ventos foram mais constantes no período das quinze horas, porém nos pontos 2, 4 e 8 não foi registrado no aparelho nenhum manifesto. Já os demais registraram valores entre $0,6 \mathrm{~m} / \mathrm{s}$ e $3,0 \mathrm{~m} / \mathrm{s}$. O registro mais expressivo foi no ponto 1 , o que pode ter contribuído para o mesmo ter menores valores térmico e higrométricos.

À noite $(21 \mathrm{~h})$ a média para a temperatura do horário foi de $21,9^{\circ} \mathrm{C}$. Nos transectos o menor registro foi no ponto rural próximo (ponto 1) com $19{ }^{\circ} \mathrm{C}$, outros dois pontos que também apresentaram valores baixos para temperatura foram o ponto 2 e o ponto 7 ambos com $20,6{ }^{\circ} \mathrm{C}$. Os valores de temperatura mais altos dos transectos foram de aproximadamente $23^{\circ} \mathrm{C}$ nos pontos 8 e 9 .

A umidade expressa no horário obteve os maiores registros do dia, com valor médio de $60,8 \%$, com $7,9 \%$ acima da média; ponto $7\left(20,6^{\circ} \mathrm{C}\right)$ também registrou os índices de umidade superiores aos demais, $65,2 \%$. Em contrapartida, o ponto $8(57,7 \%)$ e ponto $4(58,2 \%)$ apresentaram valores inferiores aos demais pontos. 


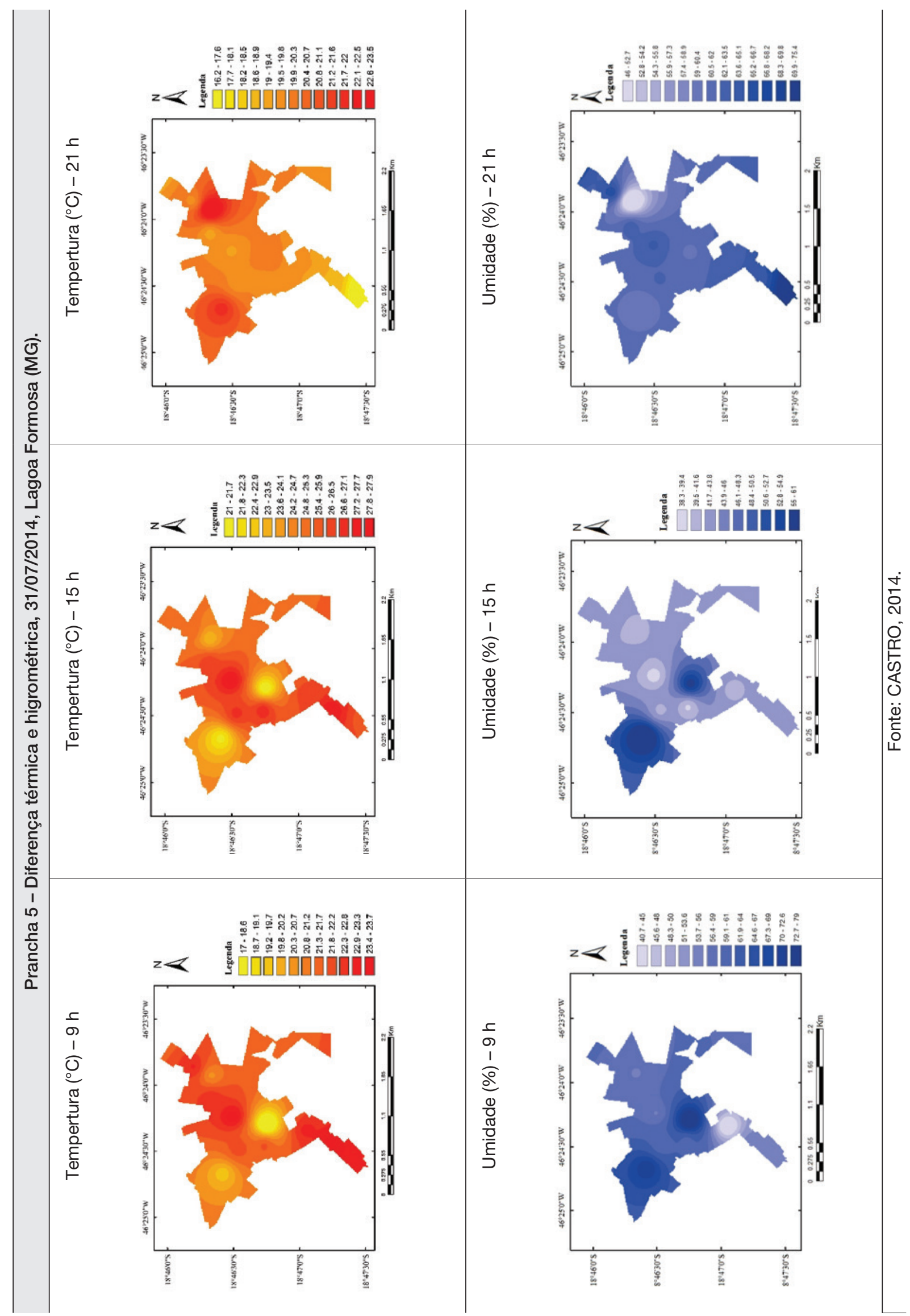




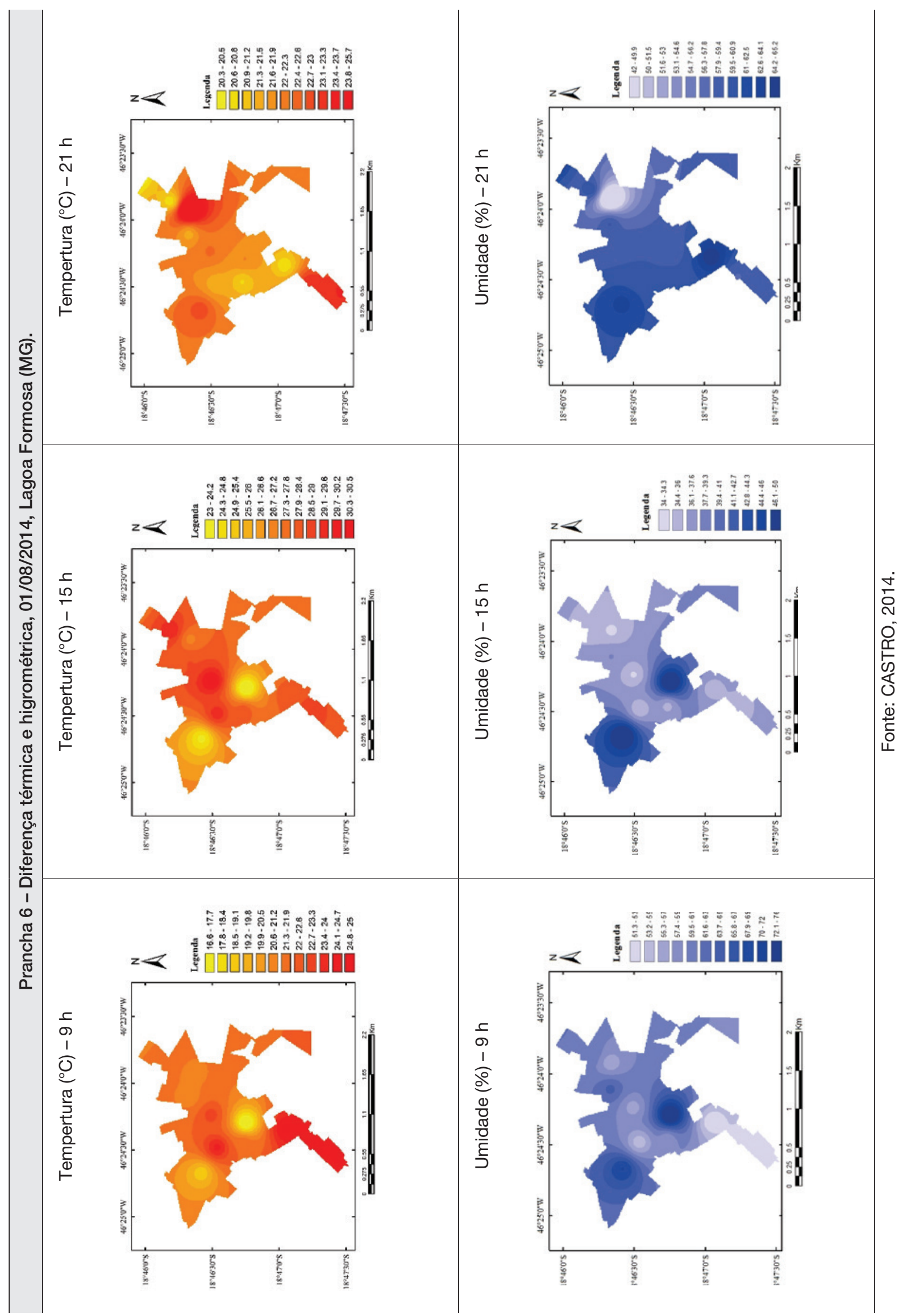


Às nove horas (dia 02 de agosto) as temperaturas tiveram uma alternância de 5,5 ${ }^{\circ} \mathrm{C}$ entre os pontos de maior e menor registro. A média foi de $23,4^{\circ} \mathrm{C}$. O ponto mais aquecido foi o ponto $8 \operatorname{com} 27,1^{\circ} \mathrm{C}$, local este que também apresentou a umidade mais baixa $48,7 \%$. A localidade é formada por casas populares muito próximas umas das outras e sem a presença de arborização, contribuindo para o aquecimento local.

Em contrapartida, as temperaturas mais amenas foram registradas no ponto fixo 1 e no transecto ponto 2 . No ponto fixo 1 a temperatura registrada foi de $17,4^{\circ} \mathrm{C}$ e no ponto 2 foi de $21,6{ }^{\circ} \mathrm{C}$, esse ponto se destaca por possuir uma arborizaçáo viária de médio porte em todo canteiro central, contribuindo, desta forma, para temperaturas mais amenas e também um menor índice higrométrico, $63,6 \%$, superado pelos pontos fixos PF1 e PF2 que registraram 81 e $69 \%$, respectivamente. Às quinze horas alguns dos pontos estiveram sob influência dos ventos, sendo esses pontos $1-1,4 \mathrm{~m} / \mathrm{s}$, ponto $2-2,0 \mathrm{~m} / \mathrm{s}$, ponto $3-1,9 \mathrm{~m} / \mathrm{s}$, ponto $4-2,6 \mathrm{~m} / \mathrm{s}$ e ponto $5-1,3 \mathrm{~m} / \mathrm{s}$ com predominância para o sentido noroeste.

No período noturno apenas o ponto 1 estava sob influência dos ventos $(0,9 \mathrm{~m} / \mathrm{s})$ na direção sudoeste. O ponto 1 foi o que apresentou menor valor de umidade $59 \%$, porém a temperatura de $19^{\circ} \mathrm{C}$ foi a média entre os pontos. Ponto 8 e ponto 9 foram aqueles cujas temperaturas estiveram abaixo da média, $16,6{ }^{\circ} \mathrm{C}$ e $17,2^{\circ} \mathrm{C}$ e a umidade de ambos os pontos foram as que apontaram o maior percentual 71,8 \% e 75,2 \%.

A espacializaçáo dos dados na prancha 7 demonstra o padrão de aquecimento pela manhã nas regióes que compreendem o centro e centro-sul da área urbana, em que os dados tiveram maior registro térmico nos pontos 8 e 4 . A espacializaçáo também aponta que nesses pontos são encontrados bolsôes de baixa umidade.

No período da tarde os mapas de temperatura e umidade mostram um padrão de índices térmicos mais amenos, com aumento considerável na umidade, nos sentidos sudoeste e centro-sul, representados pelos pontos fixos 1 e 2 , seguindo em sentido de resfriamento de sul para sudoeste, onde é encontrada a Lagoa D'água.

À noite há uma inversão e as regiôes antes representadas pelas menores temperaturas e maiores umidades durante a tarde passam a ser aquelas com temperaturas mais elevadas e umidade abaixo da média. (Prancha 7). 


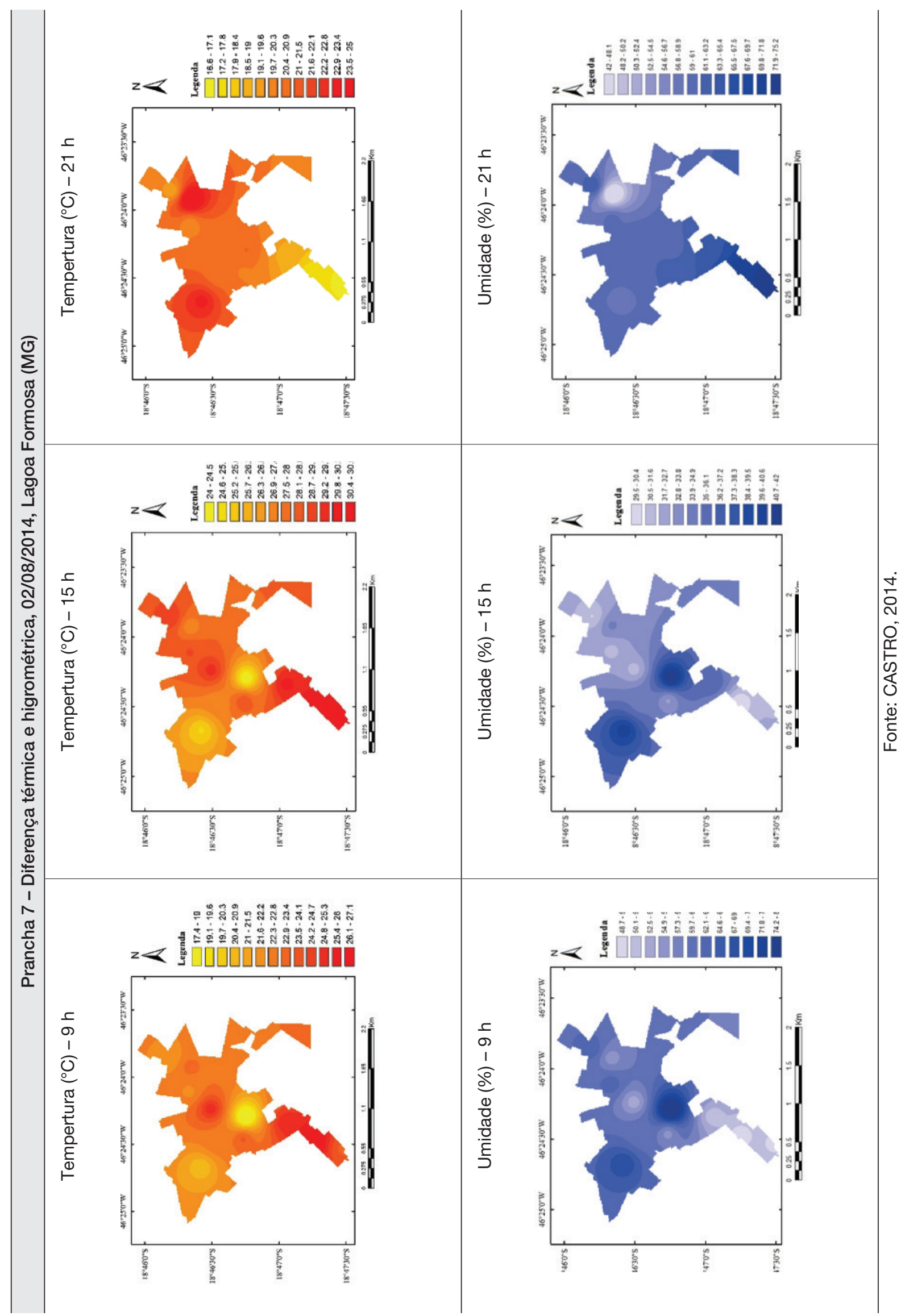


Na manhã do dia 3 de agosto, o céu permaneceu claro sem atuação dos ventos. As temperaturas tiveram variação de $5{ }^{\circ} \mathrm{C}$ entre os pontos. Os registros mostram que o ponto 8 , localizado no limiar da área rural com ocorrência de vegetaçáo circundante (eucaliptos), que podem contribuir para as variações térmicas ao longo do dia. Acreditase que no período da manhá esse tipo vegetativo impede a chegada das correntes de vento, que pode ter induzido, junto à queda da elevaçáo, o aumento da temperatura, que foi de $25,9^{\circ} \mathrm{C}$. O mesmo registrou o menor índice de umidade 49,7 \%.

Entre os pontos do transecto a menor temperatura foi novamente diagnosticada no ponto $1 \mathrm{com} 20,9{ }^{\circ} \mathrm{C}$ (umidade $62,6 \%$ ). As análises apontam para recorrência de temperaturas mais amenas no período da manhá no supracitado ponto, podendo ser associadas. a priori pela interferência dos fenômenos do rural próximo.

Às $15 \mathrm{~h}$ a média das temperaturas foi de $28,9^{\circ} \mathrm{C}$ e a higrométrica $28,2 \%$. No período foi registrado a presença de correntes de vento de até $2,0 \mathrm{~m} / \mathrm{s}$. Ao contrário do que houve no período da manhã, nesse momento do dia o ponto 1 apresentou a maior temperatura $\left(30,5^{\circ} \mathrm{C}\right)$, porém o índice higrométrico foi o maior, $35,7 \%$, se comparado aos demais, uma anomalia.

A umidade noturna manteve-se acima dos $50 \%$ nos pontos do transecto: $1-61,7$ \%, 8 - 63,2 \% e 9- 60,2 \% (próximo à área rural) registraram os maiores valores e, por conseguinte, têm permeado entre os pontos mais úmidos no período da noite. Já o ponto mais seco foi o 4 , com $53 \%$, seguindo o padrão dos dias anteriores.

A espacialização dos dados na prancha 8 demonstra o padrão de aquecimento pela manhã nas regiôes que compreendem o sul e o nordeste da área urbana, em que os dados tiveram maior registro térmico nos pontos 8 e 3. A espacialização também aponta que nesses pontos são encontrados bolsóes de baixa umidade.

É perceptível resfriamento nas áreas noroeste e nos seguimentos sentido sul/sudoeste, onde foram afixados os pontos fixos 1 e 2, se estendendo até o ponto 5 representado pela Lagoa D’água, que, com frequência, no período da manhã apresentaram temperaturas mais amenas.

Às quinze horas os mapas de temperatura e umidade mostram um padrão de índices térmicos mais amenos, com aumento considerável na umidade, nos sentidos sudoeste e centro-sul, representados pelos pontos fixos 1 e 2, seguindo em sentido de resfriamento de sul para sudoeste, onde é encontrada a Lagoa D’água. 


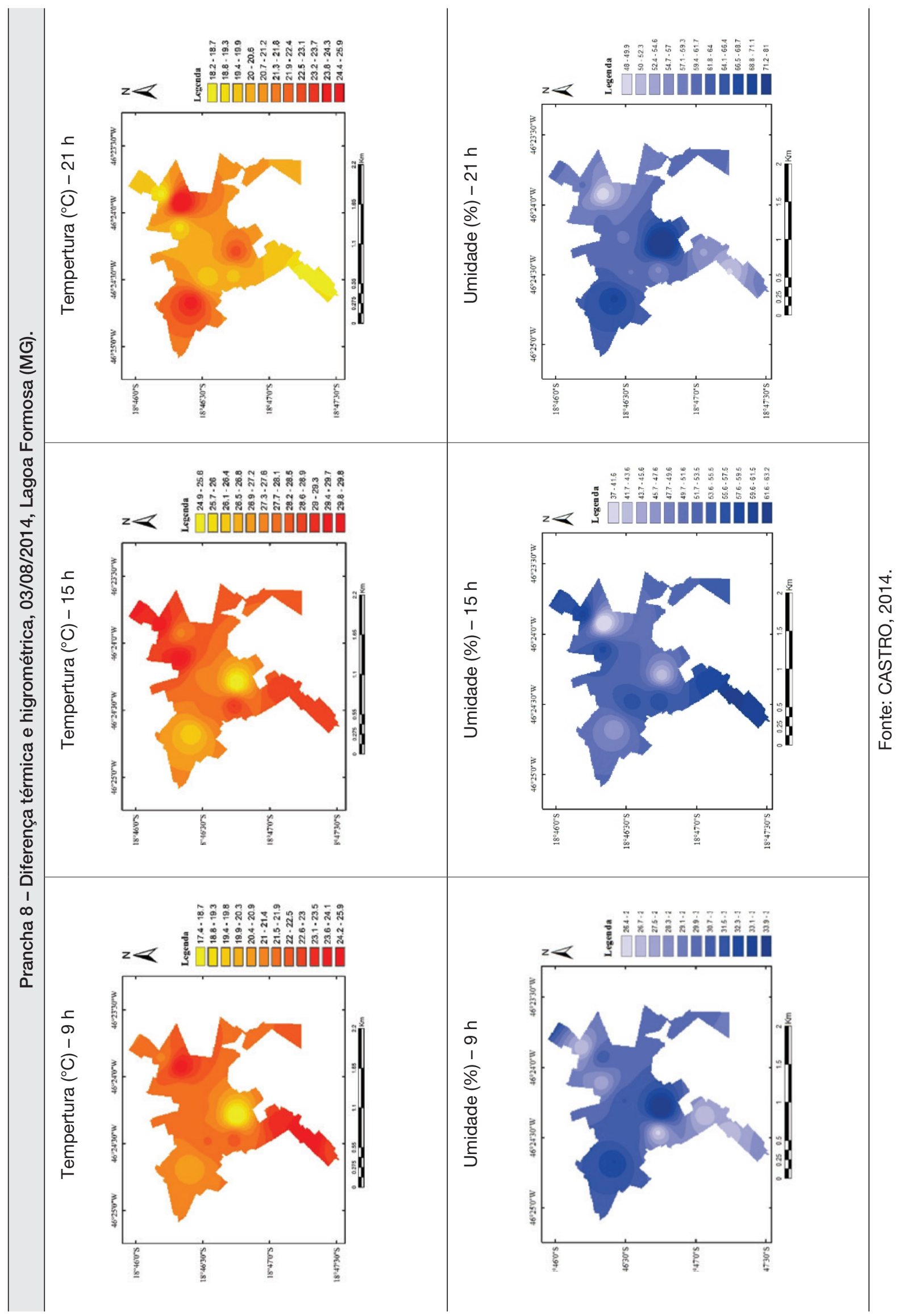


A prancha 9, demonstra o padrão de aquecimento pela manhã nas regióes que compreendem o sul, o centro, a leste e a sudoeste da área urbana, em que os dados tiveram maior registro térmico nos pontos. A espacialização também aponta que nesses pontos são encontrados bolsóes de baixa umidade. É perceptível resfriamento nas áreas noroeste e nos seguimentos sentido sul/sudoeste, onde foram afixados os pontos fixos 1 e 2, se estendendo até o ponto 5 representado pela Lagoa D’água, que com frequência no período da manhã apresentaram temperaturas mais amenas.

Às quinze horas os mapas de temperatura e umidade mostram um padrão de índices térmicos mais amenos, com aumento considerável na umidade, nos sentidos sudoeste e centro-sul, representados pelos pontos fixos 1 e 2 , seguindo em sentido de resfriamento de sul para sudoeste, onde é encontrada a Lagoa D’água. A área que novamente se apresentou mais aquecida e com baixa na umidade está novamente no extremo sul e na regiáo nordeste, onde os pontos apresentaram maior registro térmico. Às médias das temperaturas foi de $31,7^{\circ} \mathrm{C}$. O ponto 1 do transecto foi aquele que registrou a temperatura mais amena, $29,7{ }^{\circ} \mathrm{C}$. $\mathrm{O}$ mesmo registrou a umidade mais elevada, 30,7 \%, seguido pelo ponto 9, que apesar de ter a temperatura de $31,2{ }^{\circ} \mathrm{C}$, marcou $29,9 \%$ de umidade. Talvez a justificativa para esse fenômeno seja a proximidade dos pontos com a área rural.

À noite há uma inversão e as regióes antes representadas pelas menores temperaturas e maiores umidades durante a tarde passam ser aquelas com temperaturas mais elevadas e umidade abaixo da média. (Prancha 9)

Já os pontos de maior aquecimento foram 8 e 4, ambos com valor aproximado de $26{ }^{\circ} \mathrm{C}$. No ponto 8 uma justificativa para aumento na temperatura, pode estar na queda de altitude $(860 \mathrm{~m})$ em relação aos demais pontos, o que provavelmente dificulta circulaçáo dos ventos no local. Já o ponto 4 tem recorrência em altas de temperatura provavelmente pela atuação dos fenômenos diagnosticados em áreas de fluxo intenso de pessoas e veículos, pois esse se encontra na área central, abrangendo a regiáo comercial.

À tarde, a umidade nos pontos de transecto tiveram em média o registro de 35,7 $\%$. O índice mais baixo foi de $30,2 \%$ no ponto 6 , que também apresentou a maior temperatura $30,7^{\circ} \mathrm{C}$. Já o maior índice higrométrico $(45,2 \%)$ esteve presente no ponto 1 , que registrou também uma das menores temperaturas $\left(27,3{ }^{\circ} \mathrm{C}\right)$. 


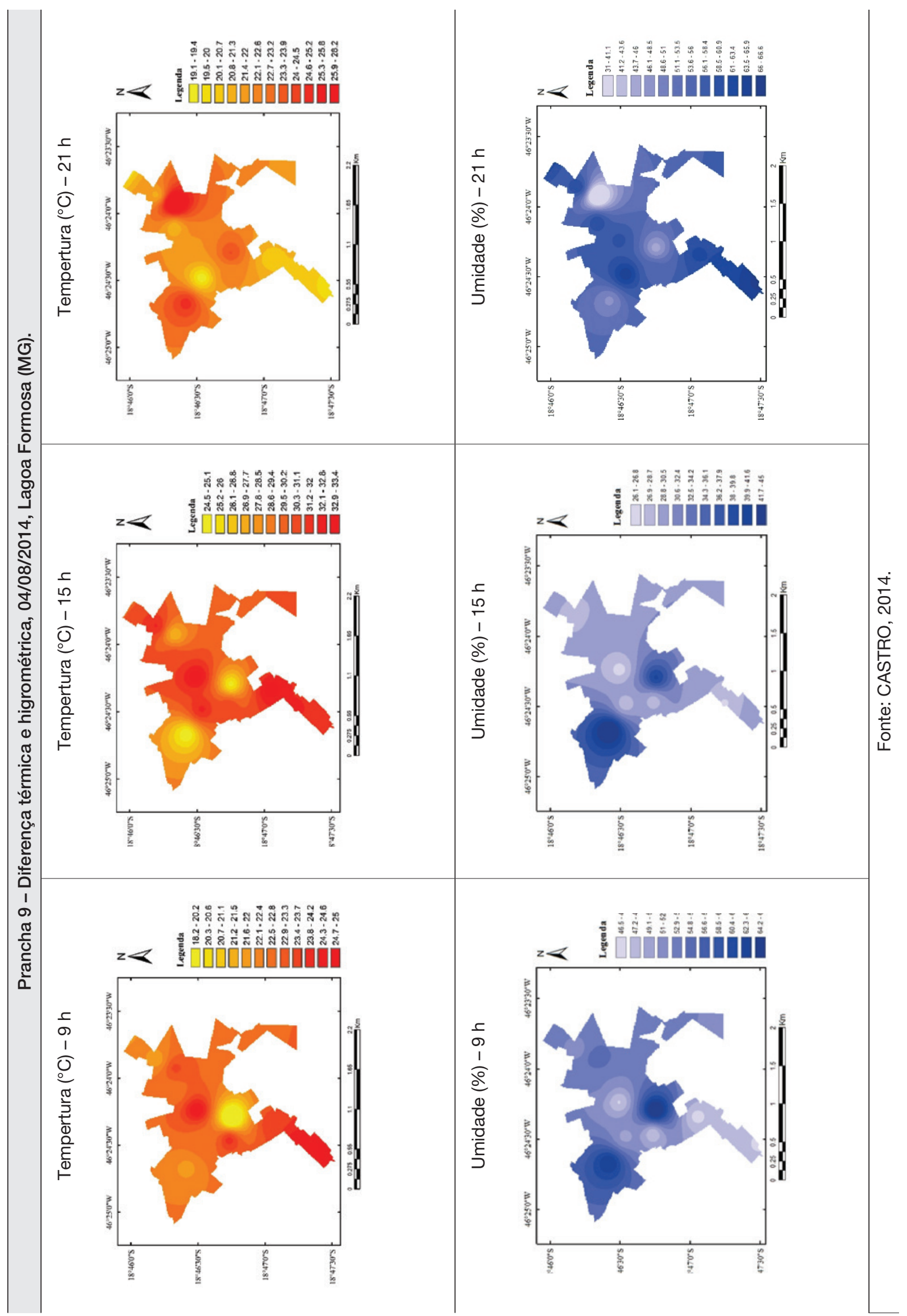




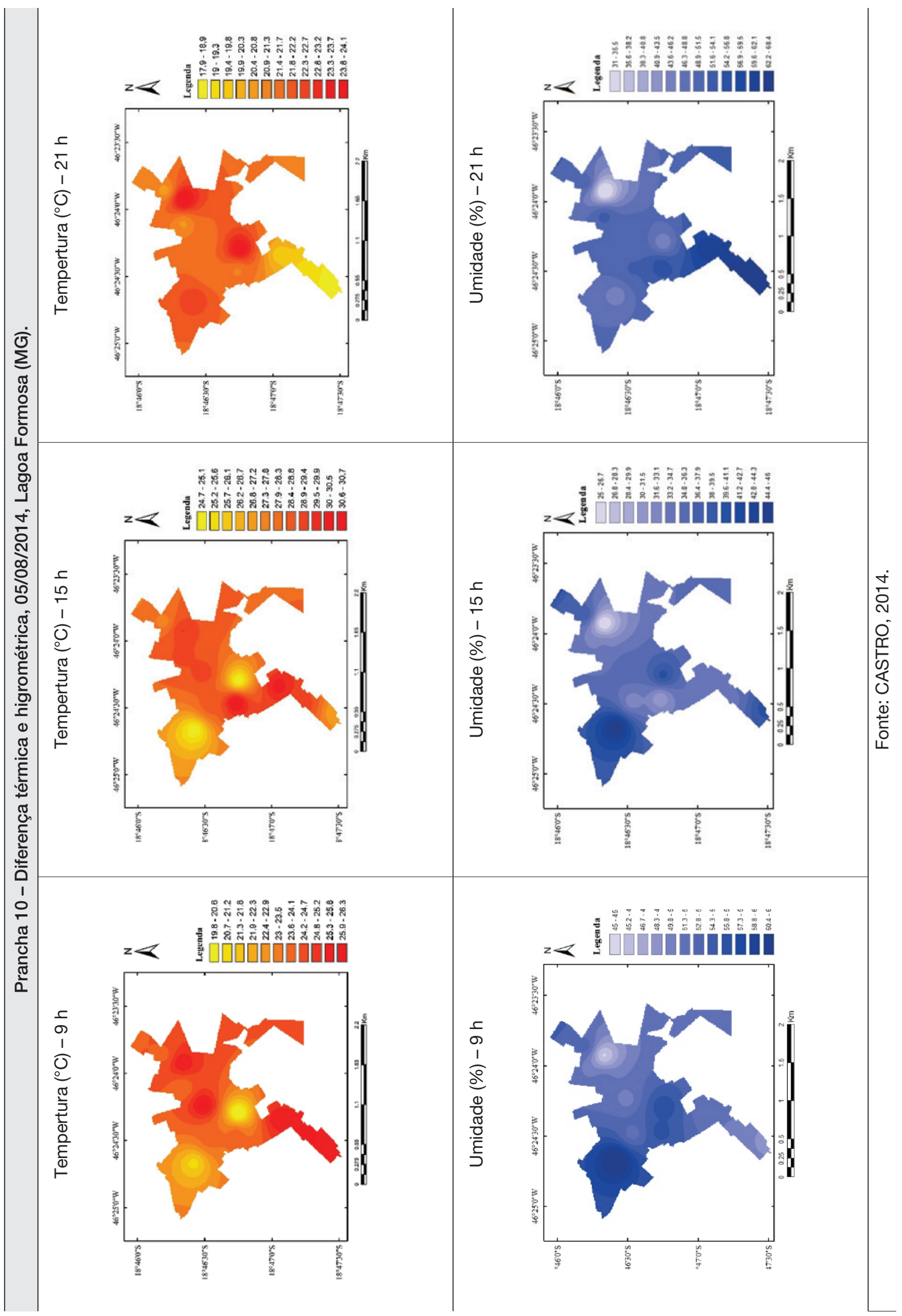


Na prancha 10 é possível notar que o maior aquecimento no período da tarde está plotado sobre as regióes central e sudoeste. Nestes mesmos sentidos são espacializadas as regióes mais secas, acompanhando a descrição das análises de dados. As regióes mais úmidas do período são aquelas apresentadas pelos pontos fixos 1 e 2 , diagnosticadas na prancha pela porção sudoeste e noroeste da malha urbana, além da extremidade sul. Nessas mesmas regiōes estão as menores temperaturas.

No período noturno $(21 \mathrm{~h})$ houve registro de ventos apenas nos pontos 4,5 e 9 , porém as velocidades não ultrapassaram $2 \mathrm{~m} / \mathrm{s}$. foram, respectivamente, registrados 0,4 $\mathrm{m} / \mathrm{s}, 0,7 \mathrm{~m} / \mathrm{s}$ e $1,1 \mathrm{~m} / \mathrm{s}$. A média para a temperatura do horário foi de $20,2{ }^{\circ} \mathrm{C}$. Nos transectos o menor registro foi no ponto próximo ao rural (P9) com $17,9^{\circ} \mathrm{C}$, outros dois pontos que também apresentaram valores baixos para temperatura foram P8 e P7, ambos na casa dos $19^{\circ} \mathrm{C}$.

À noite houve uma inversão e o ponto fixo 1 e 3, que antes apresentavam valores mais amenos de temperatura, na porção noroeste e centro-sul, no período da noite esteve mais aquecido, junto a regiáo leste da cidade que, além de mostrar um padrão térmico acima da média, também contou com a menor umidade. Já as áreas mais frias foram as extremidades sul e nordeste da área urbana com umidade mais elevada. (Prancha 10).

As distribuições espaciais temporais e as análises diárias dos valores térmicos e higrométricos tornaram possível diagnosticar que as características locais de cada ponto como a densidade e o padrão construtivo, a cobertura da terra, densidade de vegetação arbórea e altitude são elementos que contribuem para a produção de um microclima.

\section{CONSIDERAÇÓES FINAIS}

Lagoa Formosa, apesar de se enquadrar nos padrôes de uma pequena cidade, já apresenta, como a maioria dos sítios urbanos brasileiros, problemas ambientais decorrentes, em grande medida, pela despreocupação no planejamento e ordenamento do espaço urbano, acarretando impactos na qualidade de vida e no bem-estar dos citadinos. Esses impactos deveriam, a priori, chamar atenção dos responsáveis pelos núcleos urbanos, visto que esses, "continuam a ser o tipo de organização espacial onde se concentra a maioria das pessoas em escala mundial e, simplesmente por este motivo, já merecem atenção especial.” (AMORIM 2000, p. 309).

Os fatores contribuem para as variaçôes climáticas na área urbana de Lagoa Formosa (MG). Observou-se com as análises que os elementos de ordem natural, ou como foram chamados anteriormente geoecológicos ou geoambientais, como a altitude, elevação do relevo, direção e velocidade dos ventos, tiveram menos impacto sobre a variação climática. Sendo aqueles de ordem e funcionalidade estrutural urbana os que mais alteram a dinâmica climática do espaço urbano do recorte de estudo. Assim, a característica dos lotes, a presença ou não da vegetação e a maior ou menor densidade construtiva foram fatores mais representativos e relacionados com a distribuiçáo da temperatura e da umidade do ar no intraurbano. 
Dessa maneira, é possível afirmar que a ação antrópica e as alterações produzidas no ambiente, principalmente no que concerne o padrão de uso e ocupação da terra, são fatores que condicionam a temperatura e a umidade relativa do ar e contribuem para a existência de um clima específico na área urbana em cidades de pequeno porte.

Os dados apontaram que o ponto 4, localizado em área de intenso movimento de veículos e pessoas, com um padrão construtivo próprio que impede a circulação dos ventos, tem tendência a ser ambiente mais aquecido e com regióes secas, principalmente no período da tarde, quando a incidência dos raios solares sobre o ambiente é mais efetiva e a radiação solar absorvida aumenta a partir das características do material construtivo e seu poder de absorção. Outros três pontos que chamam atenção nas análises como mais aquecidos sáo ponto 2 , ponto 7 e ponto 8 , neste, o padráo de densidade construtiva e nos 2 e 8 a relativa queda de altitude, podem ter sido fatores condicionantes para as características apresentadas, nos valores térmicos e higrométricos.

Já os ambientes que demonstram temperaturas mais amenas, proporcionando um conforto térmico maior à população estão em pontos com representatividade arbórea considerável, ou ainda em pontos circundantes ao rural. O ponto 5 é um exemplo de ambiente que apresentou temperaturas mais amenas em relação ao seu entorno. A presença da Lagoa D'água no referente ponto possibilitou que o microclima estivesse que temperaturas mais amenas e índices térmicos mais elevados durante o dia, já no período noturno, pelo fenômeno de regulação térmica, houve alternância no padrão de aquecimento e resfriamento. Outro ponto com padrão arbóreo mais consolidado, localizado na Praça Ladislau Ferreira Coelho, ponto 3, esteve entre os ambientes que em média apresentaram temperatura mais amena e umidade mais elevada.

É preciso ressaltar que nem sempre os espaços intraurbanos apresentaram temperaturas mais altas que os localizados nas áreas próximo ao rural, principalmente no período noturno, quando acontece o fenômeno de inversão térmica.

Não é possível afirmar que no clima urbano de Lagoa Formosa as ilhas de calor ou frescor são produzidas, mas é possível dizer que há uma tendência de aquecimento em certos ambientes, o que ressalta a necessidade de um planejamento estratégico quanto à adequação do espaço urbano citadino. 


\section{REFERÊNCIAS BIBLIOGRÁFICAS}

AMORIM, M.C. de C. T. O clima urbano de Presidente Prudente (SP). Tese (Doutorado em Geografia) - Faculdade de Filosofia Letras e Ciências Humanas - USP, Sáo Paulo, 2000. 378 p.

ARAÚJO, H. M. O clima de Aracajú na interface com a geomorfologia de encosta. $2^{\circ}$ Seminário Ibero-Americano de Geografia Física. Universidade de Coimbra-Portugal. Coimbra, 2010.

BAPTISTA, M.C Estratigrafia e evolução geológica do Município de Lagoa Formosa (MG). 2004, 172 pág. 172 Dissertaçáo.(Mestrado em Geologia) Departamento de Geologia, Universidade Federal de Minas Gerais, 2004.

BARROS, J. R.; ZAVATTINI, J. A. Bases Conceituais em Climatologia Geográfica. Mercator, v. 08, n. 16, 2009. pp. 255-261.

CRUZ, J. C. L. Características térmicas da camada intraurbana em Rio Claro (SP). 1995. 189 f. Dissertação (Mestrado em Geografia) - Instituto de Geociências e Ciências Exatas, Universidade Estadual Paulista, Rio Claro.

FORSDYKE, A.G. Previsão do Tempo e Clima. São Paulo: Melhoramentos, 1975.

GARCÍA, F. F. Manual de climatología aplicada: clima, médio ambiente y planificación. Madrid: Sintesis, 1996. 285 p. (Serie Mayor. Coleção: Espacios y Sociedades)

INSTITUTO BRASILEIRO DE GEOGRAFIA E ESTATÍSTICA (IBGE). Cidades@ Disponível em:<http://www.cidades.ibge.gov.br/xtras/perfil.php?lang=\&codmun=313750>. Acesso em: dez. 2015.

INSTITUTO BRASILEIRO DE MEIO AMBIENTE E DOS RECURSOS NATURAIS RENOVÁVEIS (IBAMA). Ecossistemas Brasileiros. Disponível em:<http://www.ibama. gov.br/> Acesso em: dez. 2015.

MENDONÇA, F. O Clima Urbano de cidade de porte médio e pequeno: aspectos teórico-metodológicos e estudo de caso. In: SANT'ANNA NETO, J. L. (Org.). Variabilidade e mudanças climáticas: implicaçôes ambientais e socioeconômicas. Maringá: Eduem, 2000, pp. 167-192.

; DANNI-OLIVEIRA, I. M. Climatologia: noçóes básicas e climas no Brasil. São Paulo: Oficina de Textos, 2007. 206 p.

; MONTEIRO, C. A. de F. (Orgs.). Clima urbano. São Paulo: Contexto, 2.ed. 2015, 192 p.

Análise rítmica em climatologia: problemas da atualidade climática em Sáo Paulo e achegas para um programa de trabalho. Climatologia, São Paulo, n. 1, pp. $1-21,1971$.

; ___ Teoria e clima urbano. 1976. 181 f. Tese (Doutorado) - Curso de 
Geografia, Instituto de Geografia, Universidade de São Paulo, São Paulo, 1976. Cap. 4. Clima e Excepcionalismo: conjecturas sobre o desempenho da atmosfera como fenômeno geográfico. Florianópolis: EdUFSC, 1991. 241 p. $194 \mathrm{p}$. et al. A construção da climatologia geográfica no Brasil. Campinas: Alínea, 2015.

NOVAIS, G. T. Caracterização climática da mesorregião do Triângulo Mineiro/Alto Paranaíba e do entorno da Serra da Canastra (MG). 2011. 175 f. Dissertação (Mestrado) - Curso de Mestrado em Geografia, Instituto de Geografia, Universidade Federal de Uberlândia, Uberlândia, 2011. Cap. 3.

ORGANIZAÇÃO DAS NAÇÓES UNIDAS (ONU). População mundial. Disponível em:<https://nacoesunidas.org/acao/populacao-mundial/> Acesso em: ago. 2014.

ORGANIZAÇÃO MUNDIAL DE METEOROLOGIA (O.M.M.). Disponível em:<https://www.wmo.int/pages/index_es.html> Acesso em: ago. 2014.

SANTOS, A. M. Climatologia e Geologia. Departamento de Engenharia Ambiental, Fundação Universidade Federal de Rondônia, UFRO, Porto Velho. 2005.

Recebido para publicação em Agosto de 2017 Aceito para publicação em Dezembro de 2017 